\title{
Income products for the post-retirement market in Australia
}

Recerved 28th May, 2004

\section{Graham Bird}

is a consultant, based in Sydney. He advises clients on a broad range of strategic issues relating to efficient structures for the provision of employee benefits, notably on superannuation, pensions and retirement planning. He undertakes assignments for ald agencies and has recently worked on projects in China on insurance regulation, the Kingdom of Tonga on strategies for the Retirement Fund Board, and is currently workıng on a project to assist the Government of India on the introduction of their recently-announced voluntary pension scheme for the informal sector.

Abstract In this paper, the author has drawn on the experiences of his home market, Australia, to illustrate the effects of mandated contributions for accumulating retirement benefits, and the impacts of government regulation and taxation on the Australian system. The Australian retirement system is often used as a model for other countries. Matching consumer expectations for an adequate replacement income within the reality of the need for additional voluntary contributions, insufficient time horizon for older-age workers and lower than expected investment returns are the challenges now being faced.

The inadequacy of alternatives for income-producing products to service the post-retirement market was a topic for the recent Retirement Protection Seminar ${ }^{1}$ in Hong Kong. The author was a guest speaker at the seminar, giving an international perspective on developments in the post-retirement market in Australia and elsewhere. The paper expands on his speech and ends with a glossary of keywords used.

Keywords: allocated pension; index bonds; superannuation; Superannuation Guarantee Charge (SG); salary sacrifice; Three Pillars

\section{Introduction}

Although many look to the Australian retirement system as a model $^{3}$ for other nations (and as the UK often follows Australia it is touted as a paradigm for the UK), a cynic might state that it contains all three elements of the good, the bad and the ugly.

The good, is the success of the mandated system of defined contributions. It was introduced in 1992 and has elevated the thinking of most Australıans, certainly those over 40, on the subject of savings and retirement planning. Previously, less than half of the workforce was covered in superannuation plans and most had defined retirement benefits. Although not a requirement, most plans also contain elements of insured death and disablement benefits.

The bad, is the fact that it remains a lump sum system although, more and more, retirees are electing to purchase retirement income products with at least part of their lump sums. A further bad feature is the maximum 9 per cent on mandated contributions, when most projections indicate that a minımum of 15 per cent is required.

The ugly, is the fact that Australian 
superannuation plans are taxed at three levels - the only retirement system in the world to operate in that way. Initially, any contribution that attracts a tax deduction for the contributor is treated as income of the plan and taxed at the rate of 15 per cent. It applies to employer contributions, employee contributions made by way of salary sacrifice, and to contributions made by the self-employed that attract a tax deduction. In addition, a tax surcharge (up to a further 15 per cent) is levied on contributions made on account of higher income earners. The government recently announced its intention to progressively reduce the surcharge to 7.5 per cent by financial year 2007 .

The other very bad feature is the continual plethora of legislation and new regulations that impact on efficient management and planning for retirement plan issues by employers, trustees and service providers. This has seen the gradual demise of 'corporate' or enterprise-based schemes, with many employers opting to join multi-employer master trusts managed by insurers, banks and some consulting firms.

As in many countries, the Australian retirement system is based on three pillars. The old age pension provides a safety net and is seen by many as a "right of passage'. It is both assets and means tested, but within very generous limits. The second pillar is the mandated system of defined contributions $(\mathrm{SG})^{+}$that applies to most employees, but not to some casual workers and the truly self-employed (if employed through their own company it applies). The final pillar is the combination of voluntary occupational 'top-up' schemes, personal superannuation plans and private savings.

The SG system commenced in 1992 with mandatory requirements for employers to make contributions on behalf of employees. Contributions commenced at 3 per cent $(1.5$ per cent for small employers) and reached the maximum compulsory requirement of 9 per cent from July 2002. Currently, the self-employed are not required to contribute and the requirement of contributions for casual part-time workers are dependent on earning a munimum monthly wage.

Overall, SG has had a dramatic effect on the increase seen in funds under management (see Table 1).

In comparison, mones currently invested through managed funds now total AUD115 billion and in income stream products AUD46 billion.

With the ageing of populations in Australia and elsewhere, the emphasis clearly has to move to encompass the need for new products for the post-retirement market and not concentrate solely on the accumulation phase.

\section{Government policy}

As stated, the Australian system is based on the three pillars model.

The first pillar is an age pension which is non-contributory and avallable to persons reaching the specified retirement age of 65 males and 62 females (qualifying age for females is rising and by 2013 will equal the male age). The pension is means-tested aganst assets (excluding family home) and income. The age pension is based on a minimum figure of 25 per cent of male average weekly earnings measured across the country, and is adjusted each six months for inflation. For married couples the pension is 1.6 times the single rate.

Usually adequate for retirees that are home owners, it is inadequate for others. Expenditure on income support for the aged is approximately 3 per cent of GDP, a relatively low figure by comparison to other developed nations. 
Table 1: Pension assets Australia

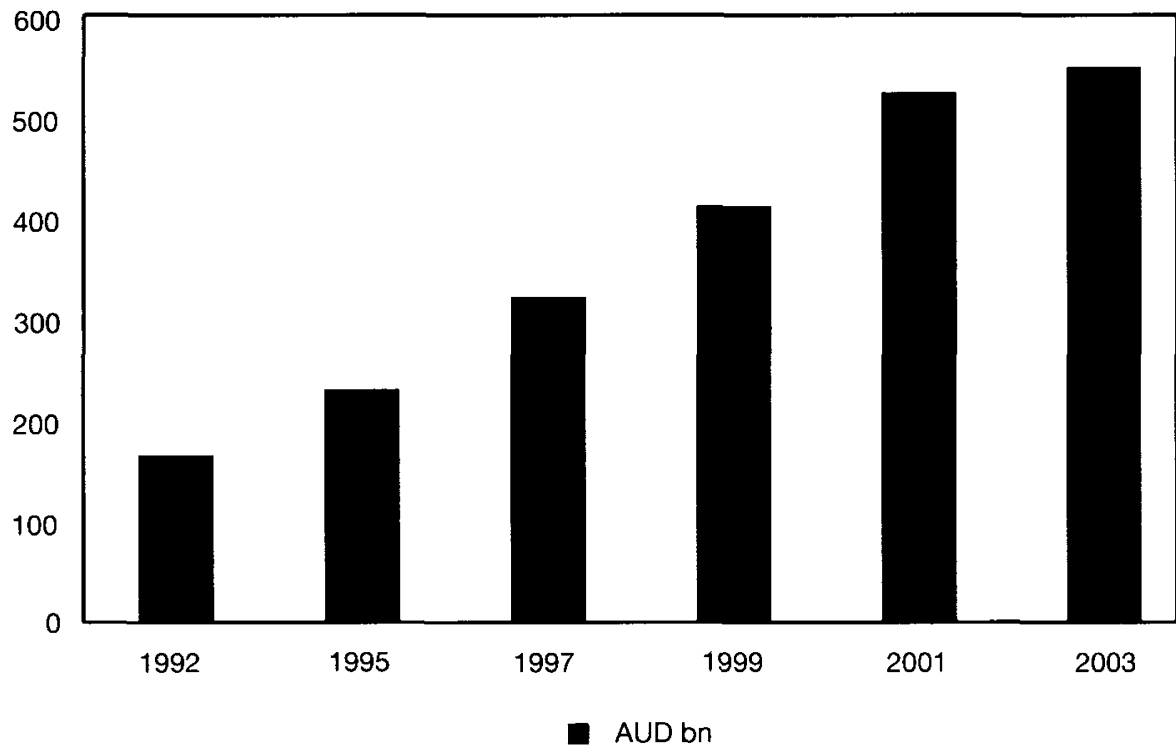

Source: Australian Prudential Regulatory Authority

This figure is expected to increase to 4.5 per cent of GDP over time. This will put Australia in a favourable position internationally and is mainly attributable to the relatively young demographic structure.

The second pillar is the superannuation guarantee charge. However, having only reached its maximum mandated rate of contribution in 1992, it will be four decades before employees entering the workforce will receive the full benefit of SG.

The third pillar is voluntary savings. The largest component of private savings for Australians is in their homes. There are no capital gains taxes attributable to dwellings used for personal occupation and this has led to many Australians investing large sums in residences. It often results in 'downsizing' the dwelling following retirement and reinvesting the surplus funds to help provide retirement income.
Levels of participation in the stock market are also high. This has been encouraged by the privatisation and sale of government entities such as Telstra and other utilities, government insurers and mutuals such as AMP. A few superannuation plans also permit limited share trading by members with individual accounts.

An increasingly significant boost to voluntary savings are additional voluntary contributions (AVCs) to superannuation. There are no limits placed on post-tax contributions. Employees may also arrange salary-sacrifice arrangements through employers, within high limits. For tax purposes, salary sacrifice is treated as employer contributions (vested in the employee, of course).

\section{Products for income in retirement}

The fastest growing product that provides an income stream in Australia is 
the allocated pension (or allocated annuity). Essentially it provides for phased withdrawals of a superannuation fund members lump sum, within annual minima and maxima set by government, based on life expectancy tables. It is outselling lifetime and other guaranteed annuity products in the ratio $2: 1$.

Although not a guaranteed lifetime pension, the product has filled a void for Australian retirees. It has become a way of weaning Australians off the lump sum mentality previously associated with superannuation.

Other pension products such as life insurance annuities, although less popular, are also available and quite frequently retirement incomes are structured through a combination of both allocated pension and lifetime annuity. This combination can help to overcome the major deficiency of the allocated pension, ie the capital may run out before death. The combination is also used in tax-planning for employees with large lump sum retirement benefits.

In spite of the obvious disadvantage, Australians have fallen in love with allocated pensions for various reasons:

- capital remains under the control of the investor, avoiding a natural aversion to parting with capital to a life insurance company for the purchase of a life annuity;

- total or partial lump sums can be withdrawn at any time after commencement of pension payments (lump sum tax is payable on the amount withdrawn);

- the pensioner is usually given choices for investment strategy, including growth assets if desired;

- as income payments for the succeeding year are recalculated annually, based on the account balance as at each 30th June, pensioners are able to budget within the maximum and minimum pension amount, for known events in the year ahead;

- in the event of death of the pensioner, residual capital reverts to a survivor or is paid out to nominated beneficiaries, or the estate of the deceased;

- as reserves do not have to be set aside, many superannuation funds offer this product to retirees, thereby avoiding the need for decisions by the retiring member on selection of a new provider;

- although the income drawn from allocated pensions is taxable, it attracts a tax rebate of 15 per cent that applies to all pension payments. For many, the rebate makes the income essentially tax-free.

As mentioned previously, the rate at which income can be drawn from an allocated annuity is determined within a range set by age-based factors. The annual pension income is calculated by dividing the capital amount at inception and each 30th June by the applicable factors. Examples of the factors are shown in Table 2 below.

\section{Experience elsewhere}

There generally appears to be a requirement for more flexible retirement

Table 2: Examples of age-based factors

\begin{tabular}{lll}
\hline at Age & $\begin{array}{l}\text { Minimum } \\
\text { pension } \\
\text { factor }\end{array}$ & $\begin{array}{l}\text { Maximum } \\
\text { pension } \\
\text { factor }\end{array}$ \\
\hline 60 & 17.8 & 9.0 \\
61 & 17.4 & 8.9 \\
62 & 17.0 & 8.7 \\
63 & 16.6 & 8.5 \\
64 & 16.2 & 8.3 \\
65 & 15.7 & 8.1 \\
66 & 15.3 & 7.9 \\
67 & 14.9 & 7.6 \\
68 & 14.4 & 7.3 \\
69 & 14.0 & 7.0 \\
70 & 13.5 & 6.6 \\
\hline
\end{tabular}


income products around the world. In comparatively low interest-rate environments, the income resulting from an investment in annuities may not be perceived as good value, particularly when add-ons such as guaranteed minimum term or spouse reversion are included with consequent reduction in the income payment.

In jurisdictions where compulsory annutisation of lump sums, either in whole or in part is required (such as in the UK), the annuitants may feel that they are receiving paltry income in return for parting with their capital. On the other hand, where annuitisation is voluntary, there is likely to be selection against the annuitant due to issuers' belief that individuals with a long expectation of life (probably based on family history) will constitute the main body of applicants. ${ }^{5}$

In a jointly sponsored World Bank/Watson Wyatt paper, ${ }^{6}$ the authors have drawn attention to the low level of development in annuity markets around the world, although there are individual exceptions such as the US. This is of particular concern when compared to the general demographic shift as populations age and will increasingly turn to the financial markets for products that provide secure retirement income.

As a possible way forward, the authors present a conceptual framework for greater risk-sharing between providers and annuitants. The overall aim would be on one hand to make products more attractive and better value for purchasers, on the other to involve lower capital investment by issuers.

It is interesting to observe that following lobbying from funds managers and industry participants, the Australian government recently announced that it will permit a new 'growth' annuity from 1st September, 2004. Little details are known as government is currently watting on the industry to make design submissions. However, the overall aim is to reduce the need for product issuers to rely on scarce government paper for conventional annuities and to increase returns by permitting investment in a higher proportion of growth assets. Risk-taking is expected to be shared between investor and issuer in a type of variable income annuity that will be issued for life or a fixed term.

Another major issue is the lack of availability of long-duration, indexed, sovereign bonds to enable issuers match liabilities for what can be very long-term contracts. There is a distinct reinvestment risk attaching to an annuity provider that can only access, say non-indexed, ten year bonds when liabilities may on average be for 20 years and indexed to inflation. This presents a real dilemma and in solving the problem, governments must take a major part in sharing some of the risk. Investment-grade bonds issued by corporations, no matter how strong now, will not be sufficient security for such long-term liabilities.

Ultimately it is a policy issue for governments that must be faced as "baby boomers' move into retirement and the ' $x$-geners' are required to make decisions about the levels of support that they are prepared to provide for the older generation through taxation. Serious planning, followed by action now will avord possible pain down the track.

Investor education is another important factor and this is an area where the financial community can, and in some places is playing an important role. However in jursdictions that have predominantly been built on, or are quickly moving to, a defined contribution base (such as in the US with their $401 \mathrm{k}$ plans), much has been focussed on the accumulation stage, whereas one of the most common questions that I hear from plan members 
is 'how much is enough?'. Providing simple facts, along with tools to enable individuals to calculate their own replacement ratio, rather than telling them what it should be will go a long way towards answering that question.

\section{Appendix A: Glossary of keywords}

'allocated pension and allocated annuity' — products that are offered by superannuation plans for phased withdrawals.

'life annuity' - an income product that can include single life annuity, joint

life/survivor annuity, term certain annuity (where income is guaranteed for a minimum term irrespective of the survival of the annuitant).

'replacement ratio' - ratio of income requirement in retirement as compared to employment income.

'salary sacrifice' - a system of forgoing salary pre-tax in return for an employee benefit. 'spouse reversion' - where income from an annuity product reverts to a spouse for his/her lifetime following death of the annuitant.

'superannuation' and 'superannuation fund' - in Australia, covers all forms of retirement plans including defined benefit plans (lump and pension) and lump sum defined contribution plans.

'Superannuation Guarantee Charge (SG or SGC)' - the Australian system of mandated contributions.

\section{References}

1 Asıan Development Bank Technical Assistance Project No 4226 - IND Pension Reforms for the Unorganised Sector

2 Seminar held 15th May, 2(0)t, jointly organised by the Hong Kong Investment Funds Association and the Hong Kong Retirement Schemes Association

3 'Averting the Old Age Crisı' - World Bank, 1998

+ Superannuation guarantec charge introduced from 1st July, 1992

5 Doyle, S and Piggott, J. 'Mandatory Annuity Design in Developing Economies' - World Bank, 2002

6 Impavido, C., Thorburn, C and Wadsworth, M (2)(13) 'A conceptual framework for retrement products - Risk-sharing arrangements between providers and retırees' - December 